\section{Information Literacy and IT Fluency Convergences and Divergences}

\section{Craig Gibson, Guest Columnist}

Correspondence concerning this column should be addressed to: Lori Arp, Assistant to the University Librarian, Northwestern University Library, 1970 Campus Drive, Evanston, IL 60208; e-mail: L-arp@ northwestern.edu.

Beth S. Woodard is Staff Development and Training Coordinator and Reference Librarian Head at the University of Illinois at Urbana-Champaign, 300 Library, 1408 West Gregory Drive, Urbana, IL 61801; e-mail:bswoodar@uiuc.edu.

Craig Gibson is Associate University Librarian for Research, Instructional and Outreach Services at George Mason University in Fairfax, Virginia.

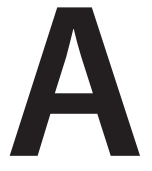
cademic librarians are currently challenged by a variety of nomenclature issues, nowhere more evident than in the expanding cluster of terms centered on concepts and processes of accessing, evaluating, and using information. This development is undoubtedly caused by the nature of library and information science itself, which is a soft applied discipline, or one without a prevailing explanatory paradigm, and with an overriding concern for application rather than pure theory. ${ }^{1}$ It is also partly caused by the multiplying educational reform agendas connected with critical thinking, resource-based learning, and a variety of pedagogies of engagement, and also by the sometimes overlapping and sometimes diverging cluster of terms centered on technology skills-information technology (IT) fluency, technology literacy, computer literacy, digital literacy, and others. This welter of terminology with converging and diverging meanings can indeed be challenging in professional discourse, particularly because librarians see a greater need than ever to collaborate with other academic professionals and with interest groups and stakeholders beyond their home institutions.

The two primary terms that have emerged in the United States that address the concepts of accessing, using, and evaluating information are information literacy and IT fluency. The two concepts have distinct lineages that are now converging in program development and curricular applications at some institutions. Information literacy is now understood by most in the academic library community as an evolving set of abilities focused on defining information needs, searching, evaluating, using, and managing information, and also understanding something of its social and legal implications. This conception of information literacy, developed in the United States, is primarily attribute- and standards-based, and assumes that there are normative and definitive characteristics of information literate students. ${ }^{2}$ IT fluency is another normative conception, with requisite knowledge and skills of IT fluent students promulgated by a group of experts from the research and academic computing communities. ${ }^{3}$ While these are the concepts used in the United States, other conceptions using the same or similar terms have emerged internationally that provide a broader context for understanding the two United States-based concepts. These other conceptions are either relational and research-based (the Bruce tradition originating in Australia), or developmental in orientationthe Seven Pillars model created by the Society of College, National, and University Libraries (SCONUL) group in the United Kingdom. ${ }^{4}$ The potential for each of these traditions to compensate or correct for deficiencies in the others is only 


\section{INFORMATION LITERACY AND INSTRUCTION}

beginning to be understood in the international arena. In the United States, only recently have the sociocultural dimensions of information literacy, as an educational reform agenda, begun to be explored. ${ }^{5}$ This article explores three diverging concepts and terms-information literacy, IT fluency, information fluency-and examines how their divergences and convergences are manifested in such emergent agendas as ICT assessment and the Partnership for 21st Century Skills.

During the late 1980s and throughout most of the 1990s, information literacy was the preferred term in the academic library community in the United States to describe a programmatic, curriculum-infused, institutional approach to research and information competency. During this time, academic librarians were challenged to consider the full implications of information literacy as a catalyst for change. A new agenda that aims to reform the curriculum includes questions of how to make sure that information literacy is not just library-sponsored, but includes many stakeholders who claim ownership. ${ }^{6}$ Equally important new agendas include the idea that learning, not just teaching or pedagogy, should be the overarching concern in program development; that the concept must include a major focus on the digital, networked environment and that the focus on the individual student as the locus of learning should be transformed to considering the social dimensions of learning. ${ }^{7}$ In effect, academic librarians, through a full consideration of the implications of information literacy, are rethinking their roles in relation to potential partners in the academy, and have begun to understand the cultural shift that is required to implement information literacy at a deep, enterprise-wide level on their campuses.

In the late 1990s, the research of Christine Bruce in Australia became widely known in the United States. Based on a research method known as phenomenography, this research focused on how a group of academic professionals actually experience information, rather than relying on experts to create normative conceptions of the information literate student or individual. Bruce called her model of information literacy a relational model because it depicts relations between people and information in realistic applications. Finding that her data from interviews with academic professionals showed certain recurring patterns, Bruce organized this relational model around seven faces or aspects of information literacy: information technology; information sources; information process; the information control; knowledge construction; knowledge extension; and wisdom. ${ }^{8}$ This model has enriched the understanding of information literacy for librarians as a construct that transcends traditional computer literacy or library literacy into a far more pervasive, knowledge-building, creativity-fused aspect of learning.

However, also in the late 1990s, the opportunities for deepening pedagogical engagement suggested by Bruce's relational model were complicated by challenges for academic librarians presented by IT fluency, a concept that grew out of the National Research Council's FITness Report of 1999 (FITness is the acronym for Fluency with Information Technology). ${ }^{9}$ This report marked a major advance on earlier notions of computer literacy, calling for education and training on foundational concepts of information technology (networks, file structures, and the like); contemporary skills (training in productivity or other software- the clearest link with the earlier notion of computer literacy); and critical thinking applied to information technology itself-its application and societal implications. This construct of IT fluency introduced the notion of fluency itself, suggesting a dynamic, maturational aspect to acquiring technology skills-an interesting link with the Seven Pillars model promoted by SCONUL, and with the lifelong learning agenda often spoken of as a related concern for policymakers influenced by the National Forum on Information Literacy, an umbrella group of educational, nonprofit, governmental, service, and professional membership organizations. ${ }^{10}$ Fluency conveys a dynamism in the learning process well-suited to highly mobile students who expect constant technological change. However, the IT fluency construct, like information literacy before it, still focuses on the capacities of the individual, and particularly calls for addressing critical thinking about technology and its applications-surely a much-needed goal, but one that does not encompass issues of engagement in the learner.

Also developed in the late 1990s, the United Kingdombased SCONUL Seven Pillars model offers academic librarians in the United States a particularly intriguing way of thinking about their nomenclature challenges. This model organizes the major elements of information literacy into seven major strands: recognizing an information need; determining ways of addressing the information gap; constructing search strategies; locating and accessing information; comparing and evaluating it; organizing, applying, and communicating it; and finally, synthesizing and creating new products based on it. Each of these elements are depicted as pillars with a spectrum of developmental stages (novice, advanced beginner, expert), so that the whole framework can be considered as a developmental paradigm. The Seven Pillars model posits that the Seven Pillars or major strands of information literacy are undergirded by two basic skill sets: basic library skills (learned through what we have traditionally called library instruction or BI), and IT skills (learned through what we have traditionally designated computer training or software training). ${ }^{11}$ The Seven Pillars model thus assumes a certain basic level of proficiency in these two domains-library and computing-before further development can occur in moving toward information literacy.

The confusion in nomenclature among academic librarians in the United States can be overcome in part by considering the Seven Pillars model for information literacy as an encompassing, expanding framework-one that includes elements of basic library skills and computer literacy as the rudiments in facilitating growth and deepened understanding, over time, of research, information access and evaluation, communicating research results, and certain stages of original or creative integration of research results. This model also shows both librarians and their academic computing counterparts that their legacy concepts of library skills and 
computer literacy are limiting and need to be connected to larger, enterprise-wide educational priorities at their institutions. Information literacy is not BI with just another trendy designation; computer literacy or IT skills themselves need to become integrated more completely into the curriculum. This same imperative for curricular integration and advancing beyond basic skills notions of information literacy receives further support from the seven faces model of Bruce, which shows deepening categories of knowledge-building and creativity that transcend computer-literacy or library literacy categories.

Complicating the nomenclature challenge, however, are the claims made by professional associations, stakeholder groups, government agencies, and others about the related sets of terms used in all levels of education to describe the information literacy agenda. Professional associations in the American library community, such as the American Library Association (ALA), American Association of School Librarians (AASL), and Association of College and Research Libraries (ACRL), have promoted information literacy as the preferred term for a number of years. They have invested much time and many resources in professional development opportunities for librarians in information literacy pedagogy and program development and created Standards (AASL's Information Power guidelines, and the ACRL-sponsored Information Literacy Competency Standards). ${ }^{12}$ These standards and professional development opportunities have assumed that information literacy is primarily an attribute of the individual student, that it may include some technology skills, and that critical thinking is the connecting element for all stages of the research process. At the level of policy development and cross-sector collaboration, the National Forum has championed information literacy in the broadest possible sense of educational reform, and has connected it with a range of other literacies: health literacy, math literacy, consumer literacy, and other agendas. Although it considers the impact of haves and have nots through discussions of the digital divide, the National Forum has not focused on technology skills, or IT fluency, except at the level of policy formulation and influence on policy makers. the National Forum has also maintained a strong focus on critical thinking as a key component of information literate individuals, and the need to infuse information literacy with content standards in K-12 and in higher education. ${ }^{13}$

As a multiple stakeholder group, the National Forum has also sought connections among all levels of education and has created conversations among policymakers that have influenced the use of the terminology focused on information, research, and technology skills. Most notably, the National Forum has influenced discussions about these skills through linkages with the Partnership for 21 st Century Skills, another multiple stakeholder group made up of major corporations, professional associations, and other organizations interested in the quality of public schools. The Partnership's preferred general term is, of course, "21st Century Skills," which includes Information and Communication Skills (including media literacy skills). ${ }^{14}$ In this model, the combination of information skills with communication skills is a natural blend; the Partnership also identifies another emerging paradigm, the Information and Communication Technology (ICT) skill set, which highlights a more integrated approach for educators, librarians, administrators, and policy makers to think about, and plan for, curriculum, assessment, and professional development. The ICT Skills conception was envisioned by the Partnership as part of a holistic set of abilities including thinking and problem-solving, civic literacy, financial and business literacy, and global awareness. The drive to connect information literacy skills with other capacities and abilities is a telling signal from this multiple stakeholder group that broader perspectives on learning are needed from all parties. For academic librarians, this conceptualization of information literacy or ICT skills as part of a broader set of learning outcomes for public school students offers one model for thinking about information literacy in a broader context at their own institutions, and also alerts them to possible $\mathrm{K}-12$ curricular changes that will influence students they will eventually see entering higher education institutions.

The emerging connections and discussions concerning information literacy and IT fluency among various levels of education in the United States are demonstrated most clearly in the development of the ICT Literacy Assessment, by the Educational Testing Service (ETS) ${ }^{15}$ This test, designed to measure "information and communication technology skills," is a scenario-based, real-time instrument that assesses students' abilities with ICT literacy (defined as "the ability to use digital technology and communications tools to succeed in an information society"). ${ }^{16}$ The tasks included in the ICT proficiencies are organized into seven categories (define, access, manage, integrate, evaluate, create, and communicate), which parallel some of the competencies identified in the Information Literacy Competency Standards for Higher Education, but with a strong infusion of technology-enabled tasks and projects that are typical of what might be expected in a college or university environment, or in the corporate world. ETS originally designed the ICT literacy assessment for higher education, but is now developing a comparable instrument for high schools. As an assessment tool, this instrument offers the clearest example of an integration of information literacy and IT fluency; the promise of this tool is that it will, in a backward design fashion, cause librarians, faculty, administrators, and academic computing professionals to create new curricular structures and reward systems to promote ICT literacy or fluency at an institutional level.

Due to all of the discussion concerning the development of these terms that describe accessing, evaluating, and using information, a new concept has emerged in recent years called information fluency. This concept blends many of the characteristics of traditional information literacy and IT fluency and similar concept such as digital literacy, or e-learning. In higher education, various institutions have implemented information fluency programs and initiatives, with somewhat different emphases. Some have focused on a wide range of 


\section{INFORMATION LITERACY AND INSTRUCTION}

contributing partners in the campus setting as training sites for a range of technology-based or -enabled skills. An example is DePauw University's information fluency program, which brings together computer science, the digital media lab, faculty instructional technology support, information services, the library, the center for contemporary media, and the university Web team to provide education and training through apprenticeships in such skill sets as programming, digital imaging, project development and instructional design, deskstop software, electronic research, video editing, and Web authoring. ${ }^{17}$ Such an approach showcases the experiential nature of information fluency as important to both traditional academic success as well as preparation for the workplace-practical applications of information and technology literacy in a liberal arts college setting. Another approach is that of the University of Central Florida (UCF), which has created an institutional information fluency plan as part of its quality enhancement plan for accreditation. ${ }^{18}$ Information fluency at UCF draws on the Information Literacy Competency Standards for Higher Education as an organizing framework, but combines those standards with technology literacy and critical thinking to create its information fluency plan. ${ }^{19}$ Notable also in the UCF plan is connection with student engagement, research-centered learning, and life skills development - an integrated set of capacities. ${ }^{20}$

The theoretical underpinnings of information fluency are still nascent because this blended learning agenda draws upon the language and preferred concepts of librarians, computing professionals, faculty, and perhaps most important, the preferences of today's students. Another professional membership organization, Educause, has recently addressed the blended nature of research and information skills in a digitally intense, networked world, with social networking, RSS feeds, Facebook and MySpace, blogs, wikis, iPods, and other ubiquitous technologies in students' lives, through a series of white papers. ${ }^{21}$ These papers identify the need for today's students to use critical thinking to evaluate information and data, whatever its sources, and discuss the challenges in learning to be thoughtful and ethical in an information-rich environment. The need for collaboration among all academic professionals in order to promote information fluency is also clear because the challenges relating to effective research, information management, and ethics cut across departmental or unit boundaries and are not limited to particular technologies, software products, computing platforms, or learning environments.

Information fluency is perhaps the optimal provisional concept for the academic library's educational mission-one that builds upon the ordered universe of knowledge and skill envisioned in the Information Literacy Competency Standards, but with technology-mediated abilities and capacities infused in a dynamic, situational way. The very unpredictability of the technology environment suggests that the fluency paradigm better addresses the need to conceive of the student as an active agent in his or her own learning. Defining, accessing, evaluating, and managing information-comprising a form of research education-is the classic skill set for information literacy. The blended learning available through infusing technology into this skill set repositions information literacy as a force for more pervasive, creative impact educational multiplier effect, both within the formal curriculum and more generally, throughout students' lives. Information literacy and IT fluency, as educational initiatives, pose large challenges for librarians, academic computing professionals, faculty, administrators, and students. The integration of learning and student experience demands a new approach to programmatic integration as well. The existing nomenclature confusion may persist but will, in time, be resolved in favor of integrative concepts and collaborations at all levels of education.

\section{References and Notes}

1. Bill Johnston and Sheila Webber, "As We May Think: Information Literacy as a Discipline for the Information Age," Research Strategies 20, no. 3 (2006): 108-121.

2. For the original exposition of the normative, attributes-based conception of information literacy, see: Christina S. Doyle, Information Literacy in an Information Society: A Concept for the Information Age (Syracuse, N.Y.: ERIC Clearinghouse on Information \& Technology, ED372763, 1994).

3. National Research Council (United States) Committee on Information Technology Literacy. Being Fluent with Information Technology. Computer Science and Telecommunications Board. Washington, D.C.: National Academy Pr., 1999.

4. See the following for the original presentation of the relational model: Christine Bruce, The Seven Faces of Information Literacy (Adelaide, Australia: AUSLIB Pr., 1997); Hilary Johnson, "The SCONUL Task Force on Information Skills," in Information and IT Literacy: Enabling Learning in the 21st Century, Allan Martin and Hannelore Rader, eds. (London: Facet Pub., 2003).

5. For an example of the relational model, based on phenomenographic research, applied in an American college setting, see: Clarence Maybee, "Undergraduate Perceptions of Information Use: The Basis for Creating User-Centered Student Information Literacy Instruction," Journal of Academic Librarianship 32, no. 1 (2006): 79-85.

6. See case studies demonstrating the efficacy of collaboration in: Dane Ward and Dick Raspa, eds., The Collaborative Imperative: Faculty and Librarians Working Together in the Information Universe, (Chicago: ACRL, 2000).

7. The shift from "transmission" models of teaching to "learner-centered" models is still underway, but the library community has been much influenced by the research first published by Robert Barr and John Tagg. This article is often cited as a landmark work in distilling needed changes in pedagogy in higher education: Robert Barr and John Tagg, "From Teaching to Learning: A New Paradigm for Undergraduate Education," Change 27, no. 6 (Nov./Dec. 1995): 13-25.; Jeremy J. Shapiro and Shelley Hughes, "Information Literacy as a Liberal Art," Educom Review 31, no. 2 (Mar./Apr. 1996): 31-35.

8. Bruce, The Seven Faces of Information Literacy.

9. National Research Council, Being Fluent with Information Technology.

10. The National Forum of Information Literacy was established in 1989 as a response to a series of recommendations by ALA's Presidential Committee on Information Literacy. The group meets three times each year in Washington, D.C. Its member organizations include government agencies, professional education and library associations, accrediting groups, nonprofit organizations, business and CEO groups, and others concerned with the connections between information literacy, lifelong learning, and personal empowerment. 